\title{
Improved development of head-fold rat embryos in culture resulting from low oxygen and modifications of the culture serum
}

\author{
D. A. T. New, P. T. Coppola and D. L. Cockroft \\ Physiological Laboratory, Cambridge CB2 3EG, U.K.
}

Previous work has shown that rat embryos can be grown in culture for periods of 1-3 days at any time during the 2 nd week of gestation, i.e. throughout the period of major organogenesis. The cultured embryos undergo extensive growth and differentiation, and many of them compare well with embryos of equivalent age in vivo. But the rate of growth, as determined by assays of total protein, has usually been found to be lower than in vivo (Berry, 1968; Shepard, Tanimura \& Robkin, 1970; Payne \& Deuchar, 1972; Robkin, Shepard \& Tanimura, 1972; New, 1973; Cockroft, 1973, 1976; Steele, 1975) and a higher proportion of the embryos show malformations (Morriss \& Steele, 1974).

This paper examines three modifications of the previous culture methods which appeared in preliminary trials to give improved development of embryos explanted at the early head-fold stage ( $9 \frac{1}{2}$ days post coitum). Such embryos have previously been cultured in a gas phase of $5 \% \mathrm{CO}_{2}$ in air, and in a nutrient medium of rat serum prepared by standard methods of decanting from clotted blood. The modifications were (i) to obtain the culture serum from blood centrifuged immediately after extraction from the rat and before clotting had occurred, (ii) 'heat-inactivation' of the serum, and (iii) reduction of the oxygen concentration in the gas phase to $5 \%$ during the first $24 \mathrm{hr}$ of the culture period.

Embryos of CFHB-strain rats were explanted with the visceral yolk sac and ectoplacental cone intact. The explants were incubated at $38^{\circ} \mathrm{C}$ in serum in small rotating culture bottles (method of New, Coppola \& Terry, 1973). In all the 48-hr cultures, the culture bottles contained $1 \mathrm{ml}$ serum/ embryo. The serum was prepared from the blood of non-pregnant female or male CFHB rats and the serum samples from different rats were pooled before use. In comparing different culture treatments, embryos from each litter were divided between the different treatments to eliminate any effects of inter-litter variation.

\section{Comparison of 'immediately centrifuged' and 'delayed centrifuged' serum}

'Immediately centrifuged' (I.C.) serum was prepared as described by Steele \& New (1974). Blood was centrifuged immediately after withdrawal from the rat to precipitate the cells. A white fibrin clot then rapidly formed in the supernatant. Then either (i) the clot was removed with forceps, the fluid being allowed to drain from it back into the centrifuge tube, which was recentrifuged and the I.C. serum decanted, or (ii) the entire contents of the tube were remixed and allowed to stand for $18 \mathrm{hr}$ before recentrifuging and decanting to give the serum designated 'I.C.-(d)'. 'Delayed centrifuged' (D.C.) serum was prepared from blood allowed to clot and stand for $18 \mathrm{hr}$ before centrifuging.

All the sera in this experiment were heat-inactivated (at $56^{\circ} \mathrm{C}$ for $30 \mathrm{~min}$ ) before use. The culture period was $48 \mathrm{hr}$ and the culture bottles were gassed with $5 \% \mathrm{O}_{2} / 5 \% \mathrm{CO}_{2} / 90 \% \mathrm{~N}_{2}$ initially, followed by $20 \% \mathrm{O}_{2} / 5 \% \mathrm{CO}_{2} / 75 \% \mathrm{~N}_{2}$ after $24 \mathrm{hr}$.

Table 1 shows that the embryos grown in I.C. serum developed better and synthesized more protein than those in D.C. serum. The $P$ value for the difference in mean protein of both groups in I.C. serum compared with the group in D.C. serum is between 0.01 and 0.02 , but the reasons for this difference are unknown. That length of time in contact with cells and clot is insufficient explanation for the harmful effects of D.C. serum is shown by the good growth obtained in I.C.-(d) serum. 
Table 1. Effects of 'immediately centrifuged' (I.C.) serum, 'immediately centrifuged but delayed-decanted' (I.C.-(d)) serum, and 'delayed centrifuged' (D.C.) serum on the growth and development of $9 \frac{1}{2}$-day rat embryos cultured for $48 \mathrm{hr}$

\begin{tabular}{|c|c|c|c|c|c|c|c|c|}
\hline \multirow[b]{2}{*}{ Serum } & \multirow{2}{*}{$\begin{array}{l}\text { Total no. } \\
\text { of } \\
\text { embryos }\end{array}$} & \multicolumn{4}{|c|}{ No. of embryos showing: } & \multirow{2}{*}{$\begin{array}{l}\text { Mean } \\
\text { yolk-sac } \\
\text { diam. } \\
(\mathrm{mm})\end{array}$} & \multirow{2}{*}{$\begin{array}{c}\text { Mean } \\
\text { somite } \\
\text { no. }\end{array}$} & \multirow{2}{*}{$\begin{array}{c}\text { Embryo } \\
\text { protein* } \\
(\mu \mathrm{g}) \\
\text { (mean } \pm \text { S.E.M.) }\end{array}$} \\
\hline & & $\begin{array}{l}\text { Blood } \\
\text { circ. }\end{array}$ & $\begin{array}{l}\text { Turning } \\
\text { complete }\end{array}$ & $\begin{array}{l}\text { Fused } \\
\text { allan. }\end{array}$ & $\begin{array}{l}\text { Closed } \\
\text { N.T. }\end{array}$ & & & \\
\hline I.C. & 12 & 10 & 12 & 11 & 12 & $3 \cdot 7$ & $23 \cdot 5$ & $137 \pm 9$ \\
\hline I.C.-(d) & 12 & 12 & 11 & 12 & 12 & $3 \cdot 6$ & $23 \cdot 2$ & $142 \pm 10$ \\
\hline D.C. & 12 & 7 & 10 & 10 & 12 & $3 \cdot 1$ & $20 \cdot 4$ & $108 \pm 11$ \\
\hline
\end{tabular}

Explanation of terms: blood circ. = a normal vigorous blood circulation in both embryo and yolk-sac at the end of the culture period; turning complete $=$ rotation to the fetal position with the ventral surface concave; fused allan. = the extension of the allantois from the hind end of the embryo and its fusion with the chorion; closed N.T. $=$ normal closure of the neural tube to form the brain and spinal cord.

* Embryo protein (without the membranes) was determined by the colorimetric method of Lowry, Rosebrough, Farr \& Randall (1951).

\section{Comparison of heat-inactivated and unheated serum}

In this experiment only 'immediately centrifuged' sera were used. The culture period was $48 \mathrm{hr}$. The effects of heat-inactivating the serum $\left(56^{\circ} \mathrm{C}\right.$ for $\left.30 \mathrm{~min}\right)$ were examined both in cultures gassed with $5 \% \mathrm{O}_{2} / 5 \% \mathrm{CO}_{2} / 90 \% \mathrm{~N}_{2}$ initially followed by $20 \% \mathrm{O}_{2} / 5 \% \mathrm{CO}_{2} / 75 \% \mathrm{~N}_{2}$ at $24 \mathrm{hr}$, and in cultures gassed with $20 \% \mathrm{O}_{2} / 5 \% \mathrm{CO}_{2} / 75 \% \mathrm{~N}_{2}$ initially and at $24 \mathrm{hr}$.

Table 2 shows that the embryos grown in heat-inactivated serum developed better and synthesized more protein than those in the unheated control serum, under both conditions of oxygenation. Typical embryos after growth in the two types of serum are shown in Pl. 1, Fig. 1.

We conclude that the beneficial effects of heat-inactivation are independent of those of immediate centrifugation.

Table 2. Effects of heat-inactivation of the culture serum, and reduced oxygen, on the growth and development of $9 \frac{1}{2}$-day rat embryos cultured for $48 \mathrm{hr}$

\begin{tabular}{|c|c|c|c|c|c|c|c|c|c|}
\hline \multirow[b]{2}{*}{ Serum } & \multirow[b]{2}{*}{$\mathrm{O}_{2}$} & \multirow{2}{*}{$\begin{array}{c}\text { Total } \\
\text { no. } \\
\text { of } \\
\text { embryos }\end{array}$} & \multicolumn{4}{|c|}{ No. of embryos showing: } & \multirow{2}{*}{$\begin{array}{l}\text { Mean } \\
\text { yolk-sac } \\
\text { diam. } \\
(\mathrm{mm})\end{array}$} & \multirow{2}{*}{$\begin{array}{c}\text { Mean } \\
\text { somite } \\
\text { no. }\end{array}$} & \multirow{2}{*}{$\begin{array}{c}\text { Embryo } \\
\text { protein } \\
(\mu g) \\
\text { (mean } \pm \text { S.E.M.) }\end{array}$} \\
\hline & & & $\begin{array}{l}\text { Blood } \\
\text { circ. }\end{array}$ & $\begin{array}{l}\text { Turning } \\
\text { complete }\end{array}$ & $\begin{array}{l}\text { Fused } \\
\text { A allan. }\end{array}$ & $\begin{array}{l}\text { Closed } \\
\text { N.T. }\end{array}$ & & & \\
\hline $\begin{array}{l}\text { Heat } \\
\text { inactivated }\end{array}$ & $\begin{array}{r}5 \rightarrow 20 \% \\
\text { d } \quad 20 \%\end{array}$ & $\begin{array}{l}24 \\
24\end{array}$ & $\begin{array}{l}23 \\
23\end{array}$ & $\begin{array}{l}23 \\
23\end{array}$ & $\begin{array}{l}20 \\
24\end{array}$ & $\begin{array}{l}24 \\
22\end{array}$ & $\begin{array}{l}3.8 \\
3.9\end{array}$ & $\begin{array}{l}23 \cdot 9 \\
24 \cdot 4\end{array}$ & $\begin{array}{l}152 \pm 8^{*} \\
159 \pm 8 \dagger\end{array}$ \\
\hline Control & $\begin{array}{r}5 \rightarrow 20 \% \\
20 \%\end{array}$ & $\begin{array}{l}24 \\
24\end{array}$ & $\begin{array}{l}24 \\
22\end{array}$ & $\begin{array}{l}17 \\
16\end{array}$ & $\begin{array}{l}19 \\
16\end{array}$ & $\begin{array}{r}20 \\
9\end{array}$ & $\begin{array}{l}3 \cdot 2 \\
3 \cdot 3\end{array}$ & $\begin{array}{l}21 \cdot 9 \\
21 \cdot 7\end{array}$ & $\begin{array}{l}113 \pm 7^{*} \\
124 \pm 8 \dagger\end{array}$ \\
\hline
\end{tabular}

Abbreviations as in Table 1.

* $\uparrow$ Significantly different, $P<0.01$

Comparison of $5 \% \mathrm{O}_{2}$ and $20 \% \mathrm{O}_{2}$

Table 2 also compares the effects of exposure to $5 \% \mathrm{O}_{2}$ and $20 \% \mathrm{O}_{2}$ during the first $24 \mathrm{hr}$ of culture. No significant difference was found in the development of the blood circulation, yolk sac and allantois, in the turning of the embryo, in the number of new somites formed or in the amount of protein synthesized, but a striking difference was noted in the development of the neural tube, particularly in the embryos grown in control serum. Of these, $15 / 24$ showed a failure of closure of the neural tube in $20 \% \mathrm{O}_{2}$ but only $4 / 24$ in $5 \% \mathrm{O}_{2}$. In heat-inactivated serum, the neural tube failed to close in $2 / 24$ embryos in $20 \% \mathrm{O}_{2}$ but in none in $5 \% \mathrm{O}_{2}$. In the abnormal embryos, usually only the brain was affected and the malformation varied from a small hole in the roof of the hind brain to wide-open neural folds extending for most of the length of the head (P1. 1, Fig. 2). In a few very deformed embryos, in which turning had also failed and the posterior part of the embryo was bent back on the anterior 

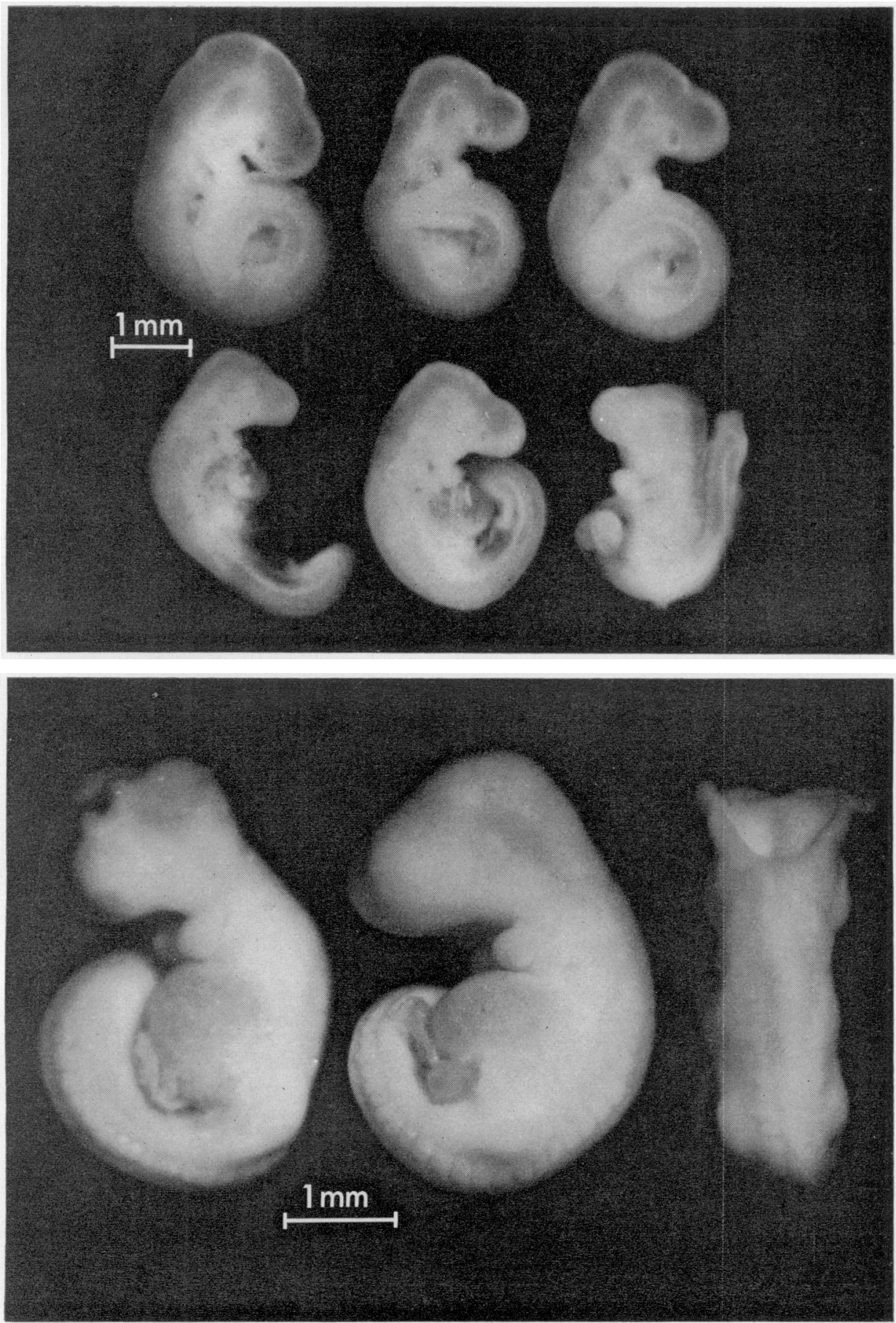

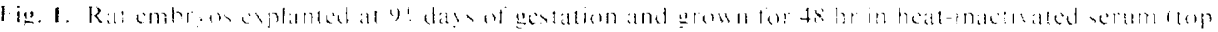

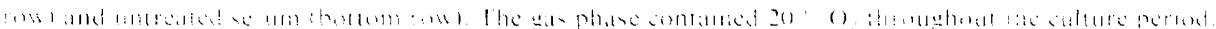

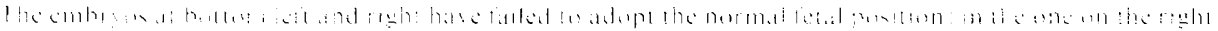

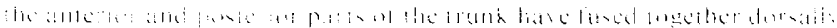

I. is. 2. f

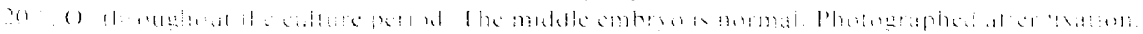




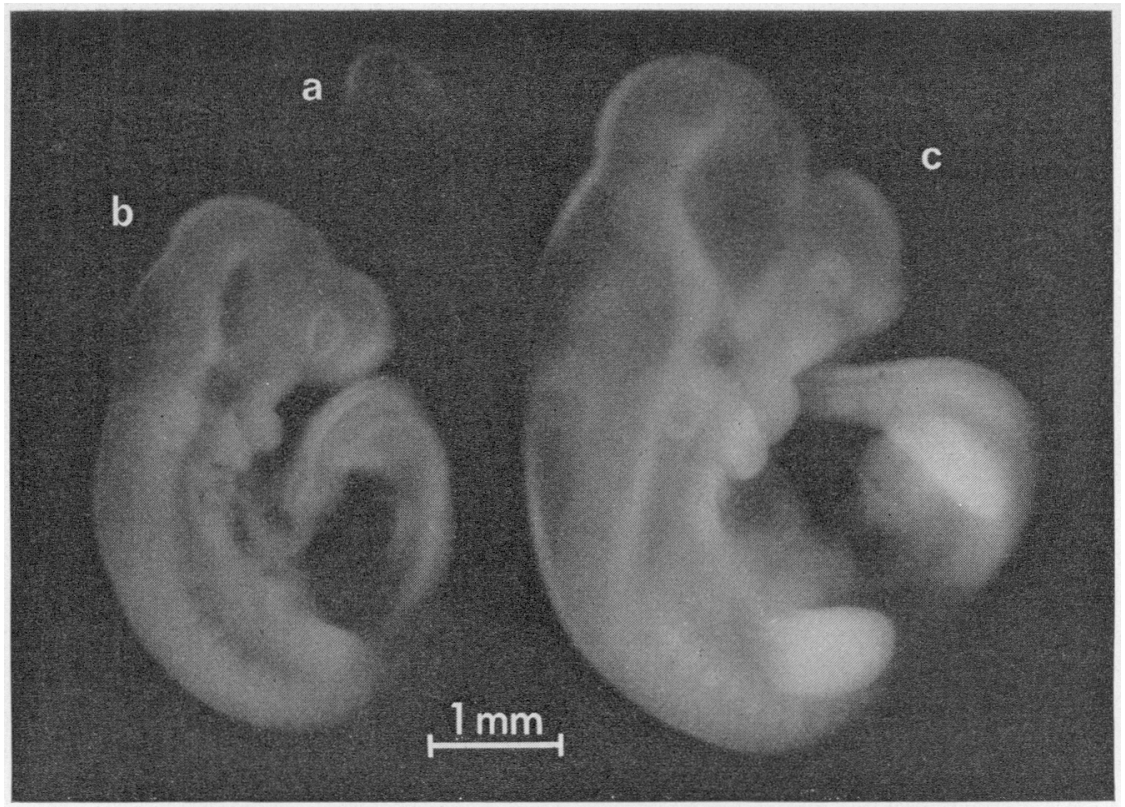

4

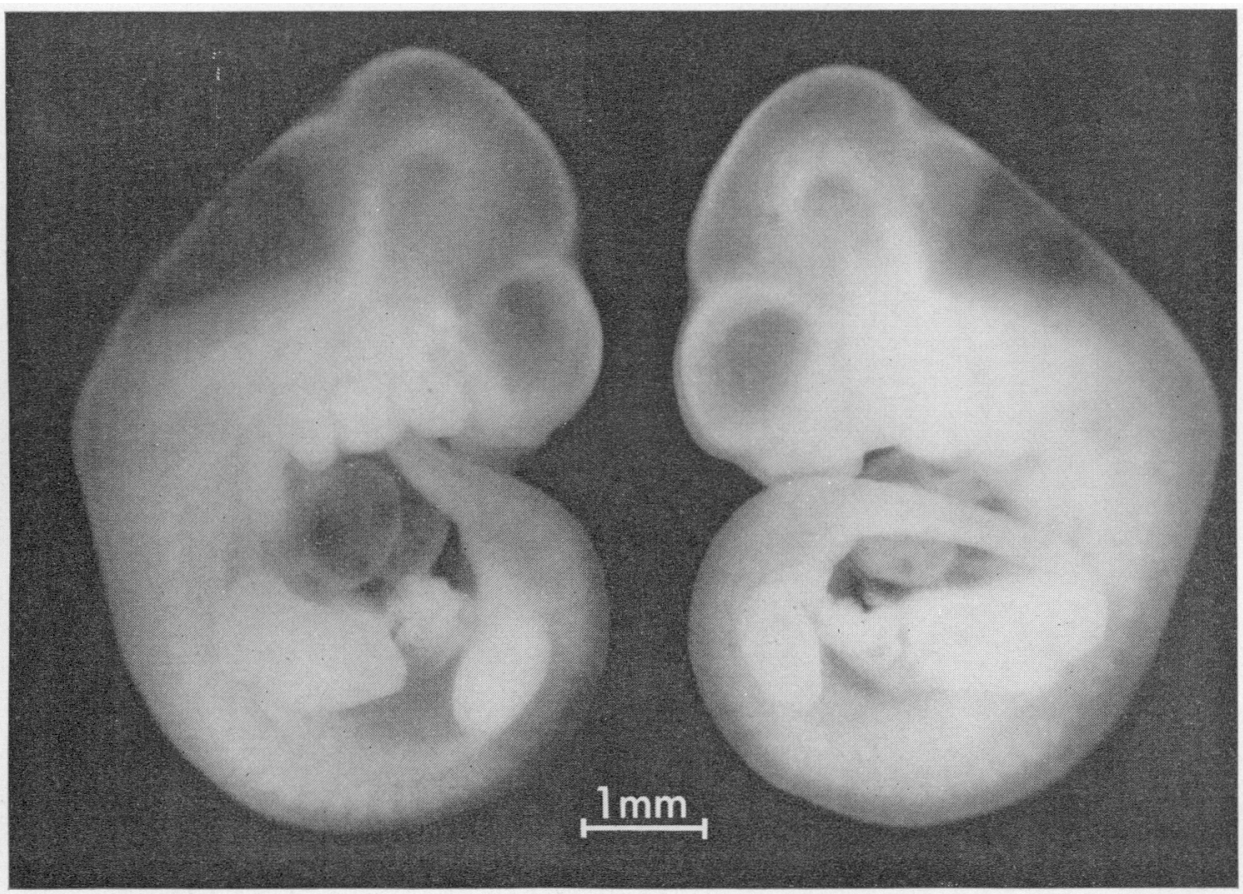

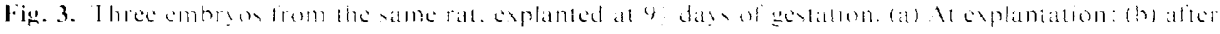

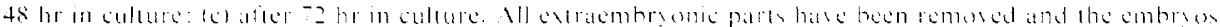

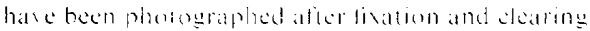

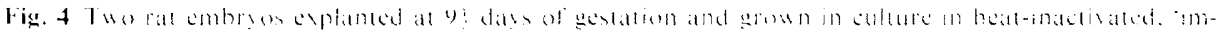

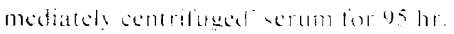


(Pl. 1, Fig. 1), the neural folds of each side remained widely separated in the mid-line over much of the length of the spinal cord while fusing together anterior to posterior.

These results confirm the earlier, unpublished, observations of $\mathrm{M}$. H. Jacobs who found the same abnormalities in 15/31 rat embryos cultured in $20 \% \mathrm{O}_{2}$. Moreover, Ferm (1964) has reported exencephaly, spina bifida and other fetal abnormalities in pregnant golden hamsters exposed to hyperbaric oxygen at stages of gestation equivalent to those of our rat embryos.

The beneficial effect obtained by reducing the oxygen of the gas phase to $5 \%$ raises the question whether this resembles more closely the oxygen concentration surrounding the conceptus in vivo than the gas mixture containing $20 \% \mathrm{O}_{2}$ that has been used previously. Yochim \& Mitchell (1968) found oxygen tensions of around $80 \mathrm{mmHg}$ in the rat aorta, $30 \mathrm{mmHg}$ in the abdominal vena cava, and in the uterine lumen a maximum of $58 \mathrm{mmHg}$ (on Day 7) during pseudopregnancy or $40-45$ $\mathrm{mmHg}$ after conception and decidualization. These values may be slightly low because they were obtained from anaesthetized animals. Comline \& Silver (1975) give values of $95-99 \mathrm{mmHg}$ for the uterine artery and $49-59 \mathrm{mmHg}$ for the uterine vein of the conscious sheep, cow and mare. An estimate based on all these data suggests that the blood in the decidua surrounding the rat conceptus has an oxygen tension in the range $40-90 \mathrm{mmHg}$. The oxygen tension in the serum in our culture bottles was calculated to be around $40 \mathrm{mmHg}$ when the gas phase contained $5 \% \mathrm{O}_{2}$ and around $160 \mathrm{mmHg}$ when the gas phase contained $20 \% \mathrm{O}_{2}$.

\section{Development in culture for $72-95 \mathrm{hr}$}

Twenty embryos were explanted at the head-fold stage and grown in culture for $72-95 \mathrm{hr}$.The culture medium throughout was heat-inactivated 'immediately centrifuged' serum. The culture bottles were gassed initially with $5 \% \mathrm{O}_{2} / 5 \% \mathrm{CO}_{2} / 90 \% \mathrm{~N}_{2}$, then at 24,32 and $48 \mathrm{hr}$ with $20 \% \mathrm{O}_{2} / 5 \% \mathrm{CO}_{2} /$ $75 \% \mathrm{~N}_{2}$ and at $54-56,72$ and $82 \mathrm{hr}$ with $95 \% \mathrm{O}_{2} / 5 \% \mathrm{CO}_{2}$. The embryos were incubated for the first $48 \mathrm{hr}$ in 30-ml culture bottles, each bottle containing 4 embryos and $4 \mathrm{ml} \mathrm{serum}$. At $48 \mathrm{hr}$, each group of 4 embryos was transferred to a $60-\mathrm{ml}$ bottle containing $8 \mathrm{ml}$ fresh serum.

Table 3. Growth and development of $9 \frac{1}{2}$-day rat embryos cultured for $72-95 \mathrm{hr}$ in heat-inactivated immediately centrifuged' serum

\begin{tabular}{|c|c|c|c|c|c|c|c|c|}
\hline \multirow{2}{*}{$\begin{array}{l}\text { Culture } \\
\text { duration } \\
\text { (hr) }\end{array}$} & \multirow{2}{*}{$\begin{array}{l}\text { Total no. } \\
\text { of } \\
\text { embryos }\end{array}$} & \multicolumn{4}{|c|}{ No. of embryos showing: } & \multirow{2}{*}{$\begin{array}{l}\text { Mean } \\
\text { yolk-sac } \\
\text { diam. } \\
(\mathrm{mm})\end{array}$} & \multirow{2}{*}{$\begin{array}{c}\text { Mean } \\
\text { somite } \\
\text { no. }\end{array}$} & \multirow{2}{*}{$\begin{array}{c}\text { Embryo } \\
\text { protein } \\
(\mu \mathrm{g}) \\
(\text { mean } \pm \text { S.E.M.) }\end{array}$} \\
\hline & & $\begin{array}{l}\text { Blood } \\
\text { circ. }\end{array}$ & $\begin{array}{l}\text { Turning } \\
\text { complete }\end{array}$ & $\begin{array}{l}\text { Fused } \\
\text { allan. }\end{array}$ & $\begin{array}{c}\text { Closed } \\
\text { N.T. }\end{array}$ & & & \\
\hline 72 & 19 & 13 & 19 & 12 & 19 & $5 \cdot 5$ & $35 \cdot 2$ & $474 \pm 38$ \\
\hline 82 & 4 & 2 & 4 & 4 & 4 & $5 \cdot 5$ & $39 \cdot 0$ & 794 \\
\hline 95 & 2 & $\mathbf{0}$ & 2 & 2 & 2 & $6 \cdot 4$ & $45 \cdot 0$ & 1570 \\
\hline
\end{tabular}

Abbreviations as in Table 1. The data for yolk-sac diameter, somite number and protein at $72 \mathrm{hr}$ exclude the 4 embryos that were returned for further incubation; similarly these data at $82 \mathrm{hr}$ exclude the 2 embryos that were returned for incubation to $95 \mathrm{hr}$.

The 19 surviving embryos (one was damaged during transfer) were examined at $72 \mathrm{hr}$. The results are summarized in Table 3 . All the embryos were well formed with an average of 35 somites; 13 still had a good blood circulation in the yolk sac, and a few showed circulation in the allantois. Four of the embryos were returned for further incubation in fresh serum. By $82 \mathrm{hr}$ the circulation in two had failed but the other two continued to develop until examined at $95 \mathrm{hr}$ (Pl. 2, Fig. 4). The blood circulation in the yolk sac of both embryos had ceased but one still had a circulation in the allantois. Both embryos appeared to be well developed, with 45 somites and prominent limb rudiments, the anterior limb being at the early 'paddle' stage.

Relative to the protein content at explantation, very large amounts of new protein were synthesized during the culture period. The embryonic part of the $9 \frac{1}{2}$-day explant contains less than $5 \mu \mathrm{g}$ protein; this was increased by about 100 -fold at $72 \mathrm{hr}$ and over 300 -fold at $95 \mathrm{hr}$ (Table 3). The relative sizes 
and overall development of three embryos explanted from one rat at $9 \frac{1}{2}$ days gestation and fixed at 0,48 and $72 \mathrm{hr}$ of culture are shown in Pl. 2, Fig. 3.

Some of the explanted embryos developed a blood circulation in the allantois in addition to that in the yolk sac. But although this represents the beginnings of an allantoic placenta, the structure lacks any maternal component and can provide little if any support for embryonic growth. This is probably the main reason why the embryos cultured for $72 \mathrm{hr}$ or longer have a lower protein content than those of equivalent age or stage of development in vivo (New, 1973). However, it is possible that during the first $30-40 \mathrm{hr}$, before the embryo has attained the stage at which the allantoic placenta acquires a supportive function, the rates of growth in vitro and in vivo may be the same (New, Coppola \& Cockroft, 1976).

We should like to thank Mrs S. M. Jackson for valuable technical assistance and the Medical Research Council for financial support.

\section{References}

BerRY, C.L. (1968) Comparison of in vivo and in vitro growth of the rat foetus. Nature, Lond. 219, 9293.

Cockroft, D.L. (1973) Development in culture of rat foetuses explanted at 12.5 and 13.5 days of gestation. J. Embryol. exp. Morph. 29, 473-483.

CoCKROFT, D.L. (1976) Comparison of in vitro and in vivo development of rat foetuses. Devl Biol. 48. 163-172.

Comline, R.S. \& Silver, M. (1975) Placental transfer of blood gases. Br. Med. Bull. 31, 25-31.

FerM, V.H. (1964) Teratogenic effects of hyperbaric oxygen. Proc. Soc. exp. Biol. Med. 116, 975-976.

Lowry, O.H., Rosebrough, N.J., FARr, A.L. \& RANDALL, R.J. (1951) Protein measurement with the folin phenol reagent. J. biol. Chem. 193, 265-275.

Morriss, G.M. \& STeele, C.E. (1974) The effect of excess vitamin A on the development of rat embryos in culture. J. Embryol. exp. Morph. 32, 505-514.

NEW, D.A.T. (1973) Studies on mammalian fetuses in vitro during the period of organogenesis. In The Mammalian Fetus in vitro, pp. 15-65. Ed. C. R. Austin, Chapman and Hall, London.

New, D.A.T., Coppola, P.T. \& Terry, S. (1973) Culture of explanted rat embryos in rotating tubes. J. Reprod. Fert. 35, 135-138.
New, D.A.T., Coppola, P.T. \& Cockroft, D.L. (1976) Comparison of growth in vitro and in vivo of postimplantation rat embryos. J. Embryol. exp. Morph. 36 (in press).

PaYNe, G.S. \& Deuchar, E.M. (1972) An in vitro study of functions of embryonic membranes in the rat. J. Embryol. exp. Morph. 27, 533-542.

Robkin, M.A., Shepard, T.H. \& Tanimura, T. (1972) A new in vitro culture technique for rat embryos. Teratology 5, 367-376.

ShePard, T.H., TANimura, T. \& Robkin, M.A. (1970) Energy metabolism in early mammalian embryos. Devl Biol., Suppl. 4, 42-58.

STEELE, C.E. (1975) The culture of post-implantation mammalian embryos. In The Early Development of Mammals, pp. 61-79. Eds M. Balls \& A. E. Wild. Cambridge University Press.

Steele, C. E. \& New, D.A.T. (1974) Serum variants causing the formation of double hearts and other abnormalities in explanted rat embryos. J. Embryol. exp. Morph. 31, 709-719.

Yochiм, J.M. \& Mitchell, J.A. (1968) Intrauterine oxygen tension in the rat during progestation. Its possible relation to carbohydrate metabolism and the regulation of nidation. Endocrinology 83, 706713.

Received 23 March 1976 